\title{
Pengaruh Penggunaan Kartu Debit dan Uang Elektronik (E- Money) Terhadap Pengeluaran Konsumsi Mahasiswa
}

\author{
Laila Ramadani \\ Fakultas Ekonomi Unversitas Negeri Malang \\ Email: lailaramadani2032@yahoo.com
}

\begin{abstract}
This study aims to determine the effect of the use of debit cards and electronic money to consumption expenditure Development Economics of students, State University of Malang. The type of this research is quantitative research, and data used is primary data from questionnaires. The analysis technique used is multiple linear regression analysis. Sample in this research is 150 students out from 240 students in Development Economics, Faculty of Economics, State University of Malang. The results indicate that according to the hypothesis test there is a positive and significant influence between the use of debit cards and electronic money to consumption expenditure of Development Economics student, State University of Malang students of 2014. The use of debit cards and electronic money also affect the students consumption expenditure. It is caused by non-cash payments are easy to use. Psychologically, anyone will spend their money easier in non-cash payment than in cash form. The results of this research indicate that Development Economics students in State University of Malang are consumptive.
\end{abstract}

Keywords: e-money, consumption expenditure, debt card

\section{PENDAHULUAN}

Pengeluaran untuk konsumsi merupakan nilai belanja yang dilakukan oleh seseorang untuk membeli berbagai jenis kebutuhannya dalam waktu tertentu. Pengeluaran konsumsi dipengaruhi oleh beberapa faktor, salah satunya adalah perkembangan teknologi. Perkembangan teknologi juga membuat sistem pembayaran mengalami perkembangan dari awalnya menggunakan uang tunai sebagai alat pembayaran hingga menjadi pembayaran non tunai. Perubahan uang sangat pesat mengikuti perkembangan teknologi, baik kertas maupun logam dengan electronic money (Adiyanti, 2015).

Pembayaran non tunai umumnya dilakukan tidak dengan menggunakan uang sebagai alat pembayaran tetapi dengan cara transfer antar bank maupun transfer intra bank melalui jaringan internal bank sendiri. Selain itu, pembayaran non tunai juga dapat dilakukan dengan menggunakan fasilitas yang diberikan bank sebagai alat pembayaran, seperti dengan menggunakan kartu ATM, kartu debit dan uang elektronik (e-money). Ketika sistem pembayaran dituntut untuk selalu mengakomodir setiap kebutuhan masyarakat dalam hal pemindahan dana secara cepat, aman, dan efisien, maka inovasi-inovasi teknologi sistem pembayaran akan berkembang dengan sangat pesat disertai berbagai fasilitas kemudahan dalam melakukan transaksi.

Dengan adanya sistem pembayaran non tunai ini membuat masyarakat terutama mahasiswa lebih mudah untuk bertransaksi. Penggunaaan kartu 
pembayaran elektronik ini merupakan pilihan bagi masyarakat, khususnya mahasiswa untuk menilai sebuah tawaran gaya hidup, menerima atau menolak sesuai dengan kebutuhan-nya. Alat pembayaran non tunai seperti kartu ATM, kartu debit dan uang elektronik (e-money) juga dapat mengatur pola hidup menjadi lebih efisien maupun lebih konsumtif. Adanya penggunaan kartu debit dan uang elektronik yang semakin meningkat dikalangan mahasiswa ini dapat mempengaruhi perilaku mahasiswa dalam berkonsumsi karena kemudahan dalam bertransaksi membuat seseorang lebih mudah membelanjakan uangnya.

Penelitian mengambil subyek mahasiswa Jurusan Ekonomi Pembangunan Universitas Negeri Malang Tahun Angkatan 2014. Pemilihan subyek mahasiswa, terlebih mahasiswa ekonomi dalam penelitian ini dianggap sangat sesuai dengan tujuan penelitian ini karena selain sebagai pengguna kartu debit dan uang elektronik, mahasiswa ekonomi pembangunan juga telah menempuh beberapa mata kuliah yang berkaitan dengan keuangan dan perbankan sehingga mereka memiliki pengetahuan yang lebih mengenai kartu debit dan uang elektronik (e-money).

\section{KAJIAN TEORI}

\section{Teori Konsumsi}

\section{Fungsi Konsumsi Simon Kuznets}

Menurut Reksoprayitno (2000:56) menyebutkan, pada tahun 1946 seorang ahli ekonomi terkenal asal Amerika mencoba mengolah data statistik tentang perekonomian Amerika Serikat yang terkumpul semenjak masa perang saudara, untuk mengetahui hubungan antara pengeluaran konsumsi masyarakat Amerika Serikat dengan tingkat pendapatan mereka.

\section{Teori Konsumsi Siklus Hidup}

Rahardja dan Manurung (2008:44) menyebutkan bahwa, teori konsumsi siklus hidup merupakan teori konsumsi yang dikembangkan oleh Franco Madigliani, Albert Ando, dan Richard Blumberg yang dikemukakan pada tahun 1950. Teori ini berpendapat bahwa kegiatan ekonomi adalah kegiatan seumur hidup. Menurut teori siklus hidup, faktor sosial ekonomi seseorang atau rumah tangga sangat mempengaruhi pola konsumsi orang atau rumah tangga tersebut.

\section{Teori Pendapatan Permanen (Permanent Income Hypothesis)}

Teori pendapatan permanen meyakini bahwa pendapatan yang mempengaruhi tingkat konsumsi. Perbedaannya terletak pada pernyataan yang menyatakan bahwa tingkat konsumsi mempunyai hubungan proporsional dengan pendapatan permanen. Yang dimaksud dengan pendapatan permanen adalah tingkat pendapatan rata-rata yang diekspektasi/ diharapkan dalam jangka panjang.

\section{Teori Pendapatan Relatif (Relative Income Hypothesis)}

Teori pendapatan relatif merupakan teori yang dikembangkan oleh James Duessenberry pada tahun 1949. Teori ini lebih memperhatikan aspek psikologis rumah tangga dalam menghadapi perubahan pendapatan. Inti dari teori konsumsi pendapatan relatif adalah tingkat konsumsi masyarakat dipengaruhi oleh tingkat pendapatan disposabel di masa yang lalu, terutama tingkat pendapatan tertinggi yang pernah dicapai, karena pola konsumsi saat ini masih dipengaruhi pola konsumsi yang lalu.

\section{Teori Konsumsi Keynes}

John Maynard Keynes lewat bukunya berjudul The General Theory of Employment, Interest, and Money, mengemukakan suatu teori konsumsi yang 
disebut teori pendapatan absolut tentang konsumsi atau lebih dikenal dengan hipotesis pendapatan absolut. Teori konsumsi dari Keynes tersebut didasarkan atas dasar hukum psikologis yang mendasar tentang konsumsi, yang mengatakan apabila pendapatan mengalami kenaikan, maka konsumsi juga akan mengalami kenaikan, tetapi dengan jumlah yang lebih kecil. Kecenderungan mengkonsumsi rata-rata akan semakin kecil apabila tingkat pendapatan naik. Kecenderungan menabung rata-rata akan semakin besar apabila pendapatan naik.

\section{Pengeluaran Konsumsi}

Menurut Samuelson (2000:88) konsumsi diartikan sebagai kegiatan menghabiskan nilai guna barang dan jasa. Konsumsi mempunyai pengertian yang luas yaitu barang dan jasa akhir yang dibutuhkan untuk memenuhi kebutuhan manusia. Barang dan jasa akhir yang dimaksud adalah barang dan jasa yang sudah siap di konsumsi oleh konsumen. Barang konsumsi ini terdiri dari barang konsumsi sekali habis dan barang konsumsi yang dapat dipergunakan lebih dari satu kali (Nopirin, 1997). Pengeluaran konsumsi rumah tangga adalah nilai belanja yang dilakukan oleh rumah tangga untuk membeli berbagai jenis kebutuhannya dalam waktu tertentu. Pengeluaran konsumsi rumah tangga merupakan komponen terbesar dari keseluruhan pengeluaran actual (Sukirno, 1994:38).

\section{Sistem Pembayaran}

Menurut Listfield dan Montes-Negret (1994:27) sistem pembayaran adalah peraturan, standar, serta instrumen yang digunakan untuk pertukaran nilai keuangan (financial value) antara dua pihak yang terlibat untuk melepaskan diri dari kewajiban. Sedangkan menurut UU Bank Indonesia No. 23/1999, sistem pembayaran adalah suatu sistem yang mencakup seperangkat aturan, lembaga, dan mekanisme yang digunakan untuk melakukan pemindahan dana guna memenuhi suatu kewajiban yang timbul dari suatu kegiatan ekonomi. Jadi dapat disimpulkan bahwa sistem pembayaran adalah sistem atau metode yang digunakan untuk menciptakan transaksi yang lebih efisien dan dalam transaksi tersebut terdapat seperangkat aturan, lembaga, dan mekanisme pemindahan dana dari pihak satu ke pihak lain guna memenuhi kewajiban dalam suatu kegiatan perekonomian.

\section{Sistem Pembayaran di Indonesia \\ Sistem Pembayaran Tunai}

Alat pembayaran yang biasa digunakan dalam pembayaran tunai adalah uang kertas dan uang logam. Uang kertas dan uang logam termasuk dalam uang kartal. Uang kartal masih berperan penting dalam kehidupan sehari-hari, khususnya dalam transaksi yang nilainya kecil.

\section{Sistem Pembayaran Non Tunai}

Jasa pembayaran non tunai yang dilakukan bank maupun lembaga selain bank baik proses pengiriman dana, penyelenggara kliring maupun sistem penyelesaian akhir (settlement) sudah tersedia dan dapat berlangsung di Indonesia. Transaksi pembayaran nontunai dengan nilai besar diselenggarakan Bank Indonesia melalui sistem BI-RTGS (Real Time Gross Settlement) dan sistem kliring. Pada tahun 2010, BI-RTGS melakukan transaksi sedikitnya Rp. 174,3 triliun per hari. Sedangkan transaksi nontunai dengan alat pembayaran menggunakan kartu (APMK) dan uang elektronik masing masing nilai transaksinya hanya Rp. 8,8 triliun perhari yang dilakukan oleh bank maupun lembaga selain bank (Bank Indonesia, 2011). 


\section{Kartu Debit/ATM}

Menurut Arthesa dan Handiman (2009:259) Perkembang-an kartu ATM sangat pesat dan memiliki manfaat dan kemudahan yang sangat luas. Manfaat tersebut adalah sebagai berikut: (1) Pengambilan uang tunai di ATM, (2) Transfer atau pengiriman uang antar rekening pada bank yang sama atau bank lain yang memiliki jaringan yang sama. (3) Pembayaran kartu kredit, listrik (PLN), telepon, dan handphone, air (PDAM), pajak bumi dan bangunan (PBB). (4) Pembelian pulsa handphone prabayar. (5) Fasilitas phone banking. (6) Fasilitas kartu debit untuk transaksi pembelian barang.

\section{Uang Elektronik}

Dalam publikasi yang di keluarkan Bank for International Settlement (BIS) pada bulan Oktober 1996 mendefinisikan uang elektronik merupakan produk yang memiliki nilai tersimpan (stored-value) atau prabayar (prepaid) dimana sejumlah uang disimpan dalam suatu media elektronis yang dimiliki seseorang. Uang elektronik (e-money) merupakan alat pembayaran yang dapat digunakan untuk berbagai macam jenis pembayaran (multi purposed), tidak seperti kartu telepon yang merupakan single-purpose prepaid card.

\section{METODE}

Populasi yang digunakan pada penelitian ini adalah seluruh mahasiswa Jurusan Ekonomi Pembangunan Fakultas Ekonomi Universitas Negeri Malang Angkatan 2014. Jumlah populasi pada penelitian ini adalah 240 mahasiswa. Sedangkan jumlah sampel dalam penelitian ini adalah 150 mahasiswa yang diperoleh dari perhitungan dengan rumus Slovin. Teknik yang digunakan dalam pengambilan sampel yaitu menggunakan metode purposive sampling. Instrumen dalam penelitian ini akan dibagi menjadi bentuk-bentuk pertanyaan terstruktur sesuai dengan variabelnya melalui angket atau kuisioner. Angket yang digunakan dalam penelitian ini adalah angket tertutup, sedangkan model jawaban berdasarkan pada model skala Likert (Sugiyono, 2009:93).

Pada penelitian ini, tahapan pertama yang dilakukan adalah pengujian instrumen yang dilakukan untuk mengetahui kualitas instrumen yang digunakan dalam penelitian. Peneliti mengambil 30 responden untuk mengisi kuisioner uji coba sebelum pengambilan sampel penelitian berjumlah 150 responden. Teknik uji validitas pada penelitian ini menggunakan korelasi product moment. Sedangkan untuk teknik uji reliabilitas menggunakan teknik Cronbach Alpha.

Teknik analisis data pada penelitian ini menggunakan teknik analisis regresi berganda. Menurut pendapat Arikunto (2006:295) menyatakan bahwa analisis korelasi atau regresi berganda ini adalah analisis tentang pengaruh hubungan antara satu variabel dependen dan dua atau lebih variabel independen. Untuk uji hipotesis dilakukan dengan dua cara yaitu uji t dan uji f. Dalam regresi ini untuk menghindari terjadinya suatu penyakit dalam suatu penelitian maka digunakan uji asumsi klasik. Uji asumsi klasik terdiri dari beberapa macam yaitu uji normalitas, uji multikolinearitas, dan uji heteroskedastisitas. Selanjutnya untuk mengetahui besarnya persentase pengaruh semua variabel independen terhadap nilai variabel dependen.peneliti dapat melihat dari besarnya kefisien determinasi. Besarnya koefisien determinasi dari 0 sampai dengan 1. Semakin mendekati 0 besarnya koefisien determinasi suatu persamaan regresi, maka semakin kecil pula pengaruh semua variabel independen terhadap variabel dependen. 


\section{HASIL DAN PEMBAHASAN}

Deskripsi subjek penelitian ini terdiri dari komposisi berdasarkan usia dan jenis kelamin. Berdasarkan usia mayoritas responden yang diamati berusia 19 tahun sebanyak 99 orang (66\%) dengan rentang usia antara 17 tahun hingga 23 tahun. Sedangkan berdasarkan jenis kelamin terdapat 61 orang laki-laki $(41 \%)$ dan 89 orang perempuan (59\%) yang digunakan sebagai subjek penelitian. Hasil uji validitas menunjukkan nilai koefisien Korelasi Product Moment (r hitung) pada seluruh butir pernyataan lebih besar dari $r$ tabel $(0,361)$ menunjukkan bahwa seluruh butir pernyataan instrumen kartu debit, uang elektronik, dan pengeluaran mahasiswa adalah valid Hasil uji reliabilitas menunjukkan bahwa instrumen variabel kartu debit, uang elektronik (e-money), dan pengeluaran konsumsi mahasiswa yang terdiri dari 6 - 12 butir pernyataan mempunyai koefisien Alpha Cronbach lebih besar dari 0,600 yang berarti bahwa instrumen variabel kartu debit, uang elektronik (e-money), dan pengeluaran konsumsi mahasiswa adalah reliabel.

Model regresi dari hasil analisis ini adalah $\mathrm{Y}=22,982+0,260 \mathrm{X} 1+0,330$ $\mathrm{X} 2+$ e dimana koefisien konstanta $\left(\beta_{0}=22,982\right)$ menunjukkan bahwa ketika nilai jawaban responden mengenai penggunaan kartu debit dan penggunaan uang elektronik (e-money) bernilai nol (0) maka nilai jawaban responden mengenai pengeluaran konsumsi mahasiswa sebesar 22,982. Koefisien regresi penggunaan kartu debit $\left(\beta_{1}=0,260\right)$ menunjukkan bahwa setiap nilai jawaban responden mengenai penggunaan kartu debit sebesar 1 satuan maka akan meningkatkan nilai jawaban responden mengenai pengeluaran konsumsi mahasiswa sebesar 0,260. Koefisien regresi penggunaan uang elektronik $\left(\beta_{2}=0,330\right)$ menunjukkan bahwa setiap nilai jawaban responden mengenai penggunaan uang elektronik (e-money) sebesar 1 satuan maka akan meningkatkan nilai jawaban responden mengenai pengeluaran konsumsi mahasiswa sebesar 0,330.

\begin{tabular}{lcc}
\hline \multicolumn{3}{c}{ Hasil Uji Parsial (uji t) } \\
\hline Variabel Bebas & t-hitung & Sig. \\
\hline X1 (Penggunaan Kartu Debit) & 4,920 & 0,000 \\
X2 (Penggunaan Uang Elektronik) & 4,725 & 0,000 \\
\hline
\end{tabular}

Sumber: Data Diolah (2015)

Variabel penggunaan kartu debit (t-hitung $=4,920>\mathrm{t}$-tabel $=1,976, \mathrm{p}=$ $0,000<\alpha=0,050$ ) yang artinya bahwa penggunaan kartu debit berpengaruh signifikan terhadap pengeluaran konsumsi mahasiswa pada taraf kesalahan $5 \%$. Variabel penggunaan uang elektronik (t-hitung $=4,725>\mathrm{t}$-tabel $=1,976, \mathrm{p}=0,000$ $<\alpha=0.050$ ) yang artinya bahwa penggunaan uang elektronik (e-money) berpengaruh signifikan terhadap pengeluaran konsumsi mahasiswa pada taraf kesalahan $5 \%$.

Hasil Uji Simultan (Uji F)

\begin{tabular}{lccccc}
\hline Model & Sum of Squares & df & $\begin{array}{c}\text { Mean } \\
\text { Square }\end{array}$ & F & Sig \\
\hline Regression & 753,541 & 2 & 376,770 & 49,776 & $0,000^{\mathrm{a}}$ \\
Residual & 1112,699 & 147 & 7,569 & & \\
Total & 1866,240 & 149 & & & \\
\hline
\end{tabular}

Sumber: Data Diolah (2015) 
Berdasarkan tabel diatas menunjukkan bahwa terdapat pengaruh signifikan antara penggunaan kartu debit dan penggunaan uang elektronik (e-money) secara bersama-sama terhadap pengeluaran konsumsi mahasiswa (F-hitung $=49,776>$ Ftabel $=3,072, p=0.000<\alpha=0,050)$. Hal ini menunjukkan bahwa perubahan secara simultan penggunaan kartu debit dan penggunaan uang elektronik (e-money) akan secara signifikan membuat perubahan pada pengeluaran konsumsi mahasiswa.

Hasil uji normalitas dengan menggunakan uji Kolmogorov Smirnov, pada penelitian ini asumsi normalitas terpenuhi. Hasil uji multikolinieritas dengan menggunakan nilai VIF juga telah terepenuhi, sehingga tidak terdapat gejala multikolinieritas pada penelitian ini. Hasil uji heteroskedastisitas dapat dilihat pada scaterplot dimana titik-titik menyebar secara acak serta tersebar baik di atas maupun di bawah angka 0 pada sumbu Y. Dengan demikian dapat disimpulkan bahwa tidak terjadi heteroskedastisitas pada model regresi.

\begin{tabular}{ccc}
\multicolumn{3}{c}{ Hasil Koefisien Determinasi } \\
\hline $\mathbf{R}$ & R Square & Adjusted R Square \\
\hline 0,635 & 0,404 & 0,396 \\
\hline
\end{tabular}

Sumber: Data Diolah (2015)

Nilai koefisien determinasi $\left(\mathrm{R}^{2}=0,404\right)$. Artinya pengaruh terhadap pengeluaran konsumsi mahasiswa dijelaskan sebesar 40,4\% oleh penggunaan kartu debit dan penggunaan uang elektronik (e-money), sedangkan pengaruh terhadap pengeluaran konsumsi mahasiswa lainnya sebesar 59,6\% dijelaskan oleh faktor lain.

Dalam penelitian ini diketahui bahwa penggunaan kartu debit memiliki hubungan positif dan signifikan terhadap pengeluaran konsumsi mahasiswa jurusan Ekonomi Pembangunan Universitas Negeri Malang angkatan 2014. Penelitian ini sejalan dengan penelitian Denis (2010) pada remaja usia kuliah penggunaan kartu ATM atau kartu debit berdampak negatif karena membuat mahasiswa lebih konsumtif. Hal ini dikarenakan dengan menggunakan kartu ATM atau kartu debit membuat kegiatan konsumsi mahasiswa menjadi lebih mudah, selain itu saat ini penggunaan kartu ATM sudah berubah fungsi menjadi gaya hidup bagi mereka. Kartu debit atau kartu ATM sebagai simbol budaya konsumen saat ini sudah menjadi trend dikalangan mahasiswa sebagai alat konsumsi yang memiliki berbagai fasilitas yang memungkinkan para penggunanya mendapatkan kemudahan pengambilan uang tunai, kemudahan pembayaran berbagai jenis tagihan serta berbagai fasilitas yang memanjakan para penggunanya contohnya diskon atau potongan harga jika membeli produk dari mitra bisnis bank yang mengeluarkan kartu debit tersebut.

Pola konsumsi seseorang pada dasarnya mulai terbentuk dari usia remaja. Pada usia ini seseorang berada pada masa peralihan dimana kebiasaan mulai terbentuk, termasuk kebiasaan dalam berkonsumsi. Karena sifat remaja yang masih labil membuatnya cenderung berkonsumsi dengan alasan yang kurang rasional seperti terpengaruh iklan dari berbagai media, meniru teman, serta kecenderungan boros (Wagner, 2009). Perilaku yang konsumtif ini membuat remaja seperti halnya mahasiswa akan membelanjakan uangnya secara berlebihan sehingga pengeluaran konsumsi mahasiswa akan meningkat.

Penggunaan kartu debit ini merupakan salah satu faktor yang mempengaruhi pengeluaran konsumsi mahasiswa, dimana semakin tinggi penggunaan 
kartu debit oleh mahasiswa maka pengeluaran konsumsi mahasiswa juga akan meningkat. Hal ini disebabkan karena secara psikologis seseorang akan lebih mudah mengeluarkan uang dalam bentuk non tunai dibanding tunai. Ini bukan soal teknologinya, tapi perilaku pertukaran (trade behaviour) manusia atas uang sebagai instrumen fisik dan non fisik. Promothesh Chatterjee, professor marketing dari University of Kansas mengatakan, ada perilaku konsumsi yang berbeda antara tunai dan nontunai. Konsumen menggunakan tunai untuk membeli barang/jasa yang memang diperlukan sehari-hari. Dalam bertransaksi tunai, konsumen fokus pada biaya atau besaran uang yang dikeluarkan. Sementara, konsumen menggunakan non tunai untuk membeli barang/jasa yang menyenangkan bagi mereka (Fajrian, 2015).

Dalam penelitian ini diketahui bahwa penggunaan uang elektronik berpengaruh positif dan signifikan terhadap pengeluaran konsumsi mahasiswa. Hasil tersebut sejalan dengan teori yang dikemukakan oleh Dias (2001) ditinjau dari segi makroekonomi, adanya penggunaan uang elektronik (e-money) akan mendorong konsumsi dan permintaan masyarakat terhadap barang dan jasa yang pada gilirannya berpotensi mendorong aktivitas sektor riil. Dewasa ini, orang enggan membawa uang dalam jumlah yang besar didalam sakunya karena selain dipandang tidak aman juga tidak praktis. Besar kecilnya uang yang dibawa dalam melakukan pembayaran dapat menjadi pertimbangan sebagai kendala keefisiensian dalam pembayaran. Kehadiran alat pembayaran non tunai seperti uang elektronik yang berbentuk kartu menghilangkan kendala tersebut dan berpotensi untuk mendorong kenaikan tingkat konsumsi (Abidin, 2015). Selain itu, kemudahan dalam berbelanja yang diberikan bagi nasabah bank yang memiliki alat pembayaran non tunai dapat mendorong kenaikan tingkat konsumsi dari nasabah tersebut (Wicaksono, 2012).

\section{KESIMPULAN}

Terdapat pengaruh positif dan signifikan antara penggunaan kartu debit terhadap pengeluaran konsumsi mahasiswa Ekonomi Pembangunan Universitas Negeri Malang angkatan 2014. Hal ini dikarenakan penggunaan kartu debit yang semakin tinggi akan meningkatkan pengeluaran konsumsi mahasiswa. Hal ini disebabkan karena secara psikologis seseorang akan lebih mudah mengeluarkan uang dalam bentuk nontunai dibanding tunai.

Terdapat pengaruh positif dan signifikan antara penggunaan uang elektronik (e-money) terhadap pengeluaran konsumsi mahasiswa Ekonomi Pembangunan Universitas Negeri Malang angkatan 2014. Hal ini dikarenakan kemudahan dan kecepatan yang ditawarkan dalam uang elekronik (e-money) sehingga penggunaan uang elektronik semakin meningkat dikalangan mahasiswa. Semakin tinggi penggunaan uang elektronik (e-money) maka semakin tinggi pula pengeluaran konsumsi mahasiswa.

\section{Daftar Rujukan}

Abidin, Muhammad S. 2015. "Dampak Kebijakan E-money di Indonesia Sebagai Alat Sistem Pembayaran Baru". Surabaya: Universitas Negeri Surabaya

Adiyanti, Arsita I. 2015. "Pengaruh Pendapatan, Manfaat, Kemudahan Penggunaan, Daya Tarik Promosi, dan Kepercayaan Terhadap Minat Menggunakan Layanan E-money". Malang: Universitas Brawijaya. 
Arikunto, Suharsini. 2006. Prosedur Penelitian: Suatu Pendekatan Praktek. Edisi Revisi. Jakarta: PT. Rineka Cipta.Arthesa, Ade \& Edia Handiman. 2009. Bank dan Lembaga Keuangan Bukan Bank. Jakarta: PT. Indeks.

Bank Indonesia. 2011. "Sistem Pembayaran di Indonesia". (online). (http://www.bi.go.id/id/sistem-pembayaran/di-indonesia/Contents/ Default.aspx, diakses tanggal 20 Agustus 2015).

Dias, Joilson. 2001. Digital Money: Review of Literature and Simulation of Welfare Improvemnet of This Technological Advance. Brazil: Departmentof Economic State University of Maringa.

Denis, Agnes N.O. 2010. Dampak Penggunaan Kartu Anjungan Tunai Mandiri Terhadap Pola Konsumsi Remaja. Skripsi tidak diterbitkan. Surakarta: Universitas Sebelas Maret.

Fajrian, Hilman. 2015. "30\% Lebih Boros Dengan Non Tunai". (online). (http://www.kompasiana.com/hilmanfajrian/30-lebih-boros-dengannontunai_55711ada2523bdf632584818, diakses 19 November 2015)

Listfield, R dan F. Montes-Negret. 1994."Modernizing Payment Systemin Emerging Economies". World Bank Policy Research Working Paper, 1336.

Nopirin. 1997. Ekonomi Makro. Cetakan Keempat. Yogyakarta: BPFE.Rahardja, P \& Manurung, M. 2008 Teori Ekonomi Makro. Edisi 4. Jakarta: Fakultas Ekonomi Universitas Indonesia.

Reksoprayitno, Soediyono. 2000. Ekonomi Makro Pengantar AnalisisPendapatan nasional. Yogyakarta: Liberty

Samuelson, Paul A \& Nordhaus,William D.2000. Makroekonomi. Jakarta: Penerbit Erlangga.

Sugiyono. 2009. Metode Penelitian Pendidikan: Pendekatan Kuantitatif, Kualitatif dan $R \& D$. Bandung: CV. Alfabeta.

Wagner. 2009. Gaya Hidup "Shopping Mall” sebagai Bentik Perilaku Konsumtif Pada Remaja di Perkotaan: Kasus Konsumen Remaja di Tiga One Stop Shopping Mall di Jakarta. Skripsi tidak diterbitkan. Institut Pertanian Bogor

Wicaksono, Danang P.A. 2012. Pengaruh Transaksi Pembayaran Menggunakan Kliring, RTGS, Kartu Kredit, ATM/Debit dan Uang Elektronik (E-money) terhadap Permintaan Uang Kartal di Indonesia. Skripsi tidak diterbitkan. Jakarta: UIN Syarif Hidayatullah. 